\title{
ДО ІСТОРІЇ КІРОВОГРАДСЬКОЇ НАСТУПАЛЬНОЇ ОПЕРАЦІЇ 2-ГО УКРАЇНСЬКОГО ФРОНТУ У СІЧНI 1944 РОКУ
}

У статті на основі архівних документів, мемуарної та історичної літератури досліджується маловідома сторінка історії Кіровоградської наступальної операції 2-го Українського фронту 5 - 16 січня 1944 року - оточення на західних і північно-західних околицях Кіровограда декількох дивізій 47-го танкового корпусу 8-ї польової армії Вермахту. Автором детально розглядаються бойові дії між німецькими і радянськими військами 6-10 січня 1944 р., чітко визначено перелік гітлерівських дивізій, які потрапили в оточення, і здійснено спробу дати характеристику їхнім втратам.

Ключові слова: Кіровоградська наступальна операція, 2-й Український фронт, 8-ма польова армія Вермахту, оперативне оточення, дивізія, роз'їз, залізнична і шосейна дороги.

Постановка проблеми та ї̈ актуальність. 5 січня 1944 р. війська 2-го Українського фронту (далі - УФ) під командуванням генерала армії Івана Конєва розпочали наступальну операцію, яка в історичній літературі отримала назву “Кіровоградська". У ході цієї операції радянським військам вдалося не лише звільнити Кіровоград, а й оточити в його околицях три дивізії 47-го танкового корпусу 8-ї польової армії Вермахту. До цього часу ці події залишаються маловивченими. Через брак архівних документів дослідники, описуючи перебіг операції, обмежуються лише загальними формулюваннями, взятими, головним чином, iз мемуарів керівників і учасників Кіровоградської наступальної операції. У присвяченій цій темі історичній літературі відсутній на достатньому рівні аналіз бойових дій радянських і німецьких військ, часто зустрічається плутанина 3 кількістю і назвами оточених ворожих дивізій. Не до кінця з'ясованим залишається питання про загальну кількість німецького угруповання, яке потрапило в оточення, а також про результати дій радянських військ із його ліквідації.

Аналіз попередніх досліджень та публікацій. Окремі аспекти історії Кіровоградської наступальної операції знайшли відображення у радянській i сучасній українській історіографії.

Шевченко Борис Леонідович, старший науковий співробітник відділу історії Кропивницького обласного краєзнавчого музею, м. Кропивницький.

(С) Шевченко Б. Л., 2018 
Підготовку і проведення операції згадують у своїх спогадах іï керівники та учасники. У період існування СРСР їхні мемуари були опубліковані та $\epsilon$ чи не найголовнішим надбанням радянської історіографії 3 цієї теми $[6 ; 15 ; 18]$. Побіжно Кіровоградська операція згадується у статтях, монографіях i збірниках документів, присвячених історії Другої світової війни у масштабах України чи Радянського Союзу.

Говорячи про сучасну українську історіографію обраної теми, варто відмітити наукові статті М.Г. Крома [16], В.М. Грицюка [3], публікації місцевих істориків В.В. Даценка [5], В.П. Колєчкіна $[13 ; 14]$ та ін.

Метою статті є дослідження одного із епізодів Кіровоградської наступальної операції, а саме - оточення військами 2-го УФ німецьких дивізій на західних і північно-західних околицях Кіровограда.

Виклад основного матеріалу. План Кіровоградської наступальної операції полягав у тому, щоб силами 53-ї армії, 5-ї гвардійської армії та 7-го механізованого корпусу обійти Кіровоград із півночі, а силами 5-ї гвардійської танкової армії та 7-ї гвардійської армії - 3 півдня і знищити кіровоградське угруповання ворога. Наступальні дії наземних військ підтримувала 5-та повітряна армія.

Протистояла радянським військам 8-ма польова армія під командуванням генерала Отто Велера. Першу лінію оборони Кіровограда німці розташовували близько 25 - 30 км східніше міста. Однак після прориву 5-6 січня 1944 р. радянськими військами німецьких оборонних порядків гітлерівські війська змушені були відступити на захід і зайняти кругову оборону Кіровограда. Наступ радянських танкових і механізованих частин у цей час був досить швидким, тому німці не зуміли повноцінно організувати оборону міста. Вже надвечір 6 січня їм стало зрозуміло, що місто не втримати. Уночі 14 танкова, 10 танковогренадерська й 376 піхотна дивізії залишили Кіровоград i відступити західніше, до околиць с. Лелеківка (нині - частина м. Кропивницький) і Злодійської балки. 14 дивізія зайняла оборону 3 східного і південно-східного напрямків, а 10 і 376 дивізії - 3 східного, північного та північно-західного напрямків. Також гітлерівці контролювали роз’їзд Лелеківка залізничної дороги Кіровоград-Шостаківка.

Тим часом, у ніч 36 на 7 січня 41-й гвардійській танковій бригаді, 63 і 64-й механізованим бригадам 7-го мехкорпусу було 
наказано о 22.30 розпочати наступ і на ранок 7 січня захопити роз'їзд Лелеківка для того, щоб перекрити шлях відступу німців iз обласного центру у західному напрямку. В 2.007 січня танки 41-ї бригади, знищивши дві артилерійські та одну мінометну батареї, а також до роти німецької піхоти, оволоділи с. Осикувате, що розташовується північно-західніше роз'їзду Лелеківка. Далі, виставивши заслін із 3 танків на північно-західних околицях Осикуватого, 41-ша бригада продовжила рух на південь у напрямку с. Обознівка. О 7.007 січня радянські танки захопили Обознівку, однак після цього вони змушені були зупинити свій наступ. Німці зруйнували переправу через місцеву річку. Відновленням переправи зайнявся саперний взвод 41-ї бригади. Затримкою наступу радянських військ скористався ворог. Станом на 9.00 німці поблизу роз'їзду Лелеківка зосередили до 12 танків різного типу, чотири артбатареї великого калібру, бронепотяг, який курсував по залізниці Кіровоград-Шостаківка і до двох рот піхоти на бронетранспортерах [10, арк. 242]. О 10.30, відбивши атаку ворога, радянські танки оволоділи роз'їздом Лелеківка. Однак ненадовго. О 12.30 гітлерівці силою до 40 танків із піхотою перейшли в контрнаступ із напрямку Кіровограда. 41-ша танкова бригада змушена була відступити на північну околицю Обознівки.

О 20.007 січня 41-ша бригада отримала наказ прорватися через бойові порядки ворога i до світанку 8 січня вийти в околицю Соколівських хуторів, що були значно південніше роз’їду Лелеківка. Прибувши у зазначене місце, 41-ша бригада з'єдналася 3 частинами 5-ї гвардійської танкової армії і стала на перепочинок. 8 січня наступальних дій вона не проводила. О 17.309 січня їй було наказано розпочати наступ із околиць Соколівських хуторів у напрямку на Лелеківку і Обознівку. До кінця дня 41-ша бригада захопила роз'їд Лелеківка і вийшла на північно-західні околиці Обознівки [10, арк. 244].

Аналізуючи дії 41-ї танкової бригади 7 - 9 січня, можна зробити висновок, що роз’їзд Лелеківка так і не був повністю взятий під контроль радянськими військами. Відповідно, німці зберігали можливість виходу з оточення у Лелеківці.

Але радянським військам вдалося повністю перекрити шлях відступу німцям на південь і південний захід. Передові частини 18-го танкового корпусу 5-ї гвардійської танкової армії 7 січня вийшли до околиць с. Нова Павлівка і перекрили шосейну дорогу 
Кіровоград-Рівне. 8 січня 18-му корпусу було наказано наступати на південний захід від Нової Павлівки [9, арк. 54;56]. Поруч із частинами 18-го корпусу діяв 29-й танковий корпус, який станом на $19.00-20.007$ січня також контролював шосейну дорогу Кіровоград-Рівне.

Таким чином, 18-й і 29-й корпуси, виконавши своє початкове завдання із перекриття шосейної дороги Кіровоград-Рівне, не стали наступати на північ, до роз'їзду Лелеківка, а повернули свої сили в протилежний бік. Коли б частини корпусів все ж продовжили свій наступ на північ і допомогли б 5-ї армії повністю взяти під контроль залізничну дорогу КіровоградШостаківка i шосейну дорогу Кіровоград-Велика Виска, то німецькі війська у Лелеківці опинилися б у цілковитому оточені. Однак реальна ситуація виявилася іншою.

Радянські війська зуміли оточити 14-ту танкову, 10-ту танково-гренадерську й 376-ту піхотну дивізії 47-го танкового корпусу лише в оперативному плані, тобто німецькі війська зберігали можливість відступу. Слабкими місцями у кільці оточення залишалися західний і північно-західний напрямки, де підрозділи 5-ї армії не мали стійких позицій.

7 січня 1944 р. зі ставки Адольфа Гітлера надійшов наказ, у якому Лелеківка оголошувалася «фортецею», а розташовані в ній дивізії мали залишатися на своїх місцях i якомога довше стримувати наступ радянських частин, доки розрив на фронті не буде ліквідовано.

Якою ж була чисельність оточеного під Кіровоградом німецького угруповання? Точної відповіді на це питання ані опрацьована література, ані архівні документи не дають. $Є$ окремі відомості, спираючись на які можна лише приблизно скласти уявлення про кількісні показники оточених німецьких частин.

Наприклад, у Журналі бойових дій 5-ї гвардійської армії вказується, що станом на 19.007 січня в оточенні перебуває німецьке угруповання кількістю 50 танків, 2-3 тис. піхоти і 3 багатьма автомобілями [11, арк. 25]. Історик В. Колєчкін у своїй статті «Авиация в боях под Кировоградом в январе 1944 г.» зазначає іншу кількість оточених у районі Лелеківки німців: 15 тис. солдат і офіцерів [13, с. 51].

Учасник січневих боїв під Кіровоградом військовий кореспондент Борис Полєвой згадує: «Нам сказали, что у Лелековки сосредоточилось сейчас около пяти тисяч пехотинцев, около ста танков и много артиллерии...» $[17$, с. 478]. 
8 січня 1944 р. командувач 2-им УФ генерал армії І.С. Конєв віддав наказ 5-й гвардійській армії знищити оточені у Злодійській балці і Лелеківці німецькі війська і перейти в наступ у загальному напрямку на Велику Виску. Протягом ночі 37 на 8 січня підрозділи армії закріпилися на досягнутих позиціях і розпочали підготовку до наступу. Станом на 4.008 січня 468 і 399-й гвардійські стрілецькі полки 111-ї гвардійської стрілецької дивізії вийшли південніше с. Осикувате i зайняли оборону 3 метою недопущення прориву німецьких військ, які перебували в оточенні у північно-західному напрямку. Вночі 37 на 8 січня 6-7 німецьких танків за підтримки роти піхотинців тричі безуспішно атакували позиції радянських військ.

8 січня близько 12.006 німецьких танків рухалися у напрямку Лелеківки з Осикуватого, але через вогонь радянських військ змушені були повернутися на попередні позиції. О 16.00 німці знову здійснили спробу прорватися до своїх частин, які перебували в оточенні. Бойові порядки 468-го стрілецького полку, які розташовувалися у с. Осикувате 3 напрямку с. Лісне, атакували більше 40 танків за підтримки піхоти і авіації. Як зазначається у Журналі бойових дій 111-ї стрілецької дивізії, 468-й стрілецький полк не встиг повністю закріпитися на позиціях до атаки німців і тому змушений був відступити з Осикуватого в Обознівку [8, арк. 2].

399-й стрілецький полк уночі 37 на 8 січня вів бій із німцями (танки і колона автомобілів), які намагалися вирватися з оточення у напрямку на північний захід. О 14.008 січня полк перейшов у наступ, однак через сильний вогонь ворога успіху не досягнув. Документи також фіксують дії протягом 8 січня німецької авіації: періодично розташування радянських військ бомбардували групи від 9 до 12 літаків [8, арк. 28].

9 січня командувач 2-м УФ генерал армії І.С. Конєв знову віддав наказ військам 5-ї гвардійської армії ліквідувати вороже угруповання і розвернути наступ на с. Грузьке. У свою чергу командувач 5-ї армії генерал-лейтенант О.С. Жадов наказав командиру 32-го стрілецького корпусу генерал-майору О. І. Родимцеву силами 110, 111, 97, 95 і 214-ї дивізій наступати з фронту Осикувате-Лелеківка на Грузьке, а частиною сил, взаємодіючи з 7-им механізованим і 33-им стрілецьким корпусами, знищити оточених під Кіровоградом гітлерівців. Остаточним результатом 
наступу радянських військ 9-го січня мав стати їх вихід на лінію Олександрівка-Овсяниківка-Івано-Благодатне [11, арк. 38].

9 січня 1944 р. німці провели наступ і дещо потіснили позиції 5-ї армії, але іiі частини зуміли стримати ворога і перейти у контратаку. Станом на 18.00 підрозділи 5-ї армії досягли Злодійської балки і впритул (1 км) наблизилися до роз'їзду Лелеківка, вийшли на східні околиці с. Карлівка. Але попри ці успіхи не виконаними залишилися завдання з ліквідації оточених під Кіровоградом гітлерівців і вихід на лінію ОлександрівкаОвсяниківка-Івано-Благодатне. Крім того, 9 січня німцям вдалося провести досить успішний наступ на с. Грузьке. Із південнозахідного напрямку населений пункт був атакований 331-им охоронним батальйоном, а 3 південного сходу - 3-им батальйоном 36-го танкового полку. Німці зуміли розвинути наступ до Обознівки. Завдяки одночасним із наступом атакам підрозділів 3-ї танкової дивізії гітлерівці майже повністю відтіснили радянські війська з околиць Грузького. У радянських військ поблизу цього села залишилися лише окремі позиції. Метою наступу німців 9 січня на Грузьке було прагнення послабити міцність кільця оточення і підготувати коридор для відступу своїх військ із Лелеківки [2, с. 195].

Радянські війська проводили наступ на оборонні позиції оточених у Лелеківці дивізій головним чином із півдня і сходу. Наприклад, 8 січня у складне становище потрапили саперний i розвідувальний батальйони 14-ї танкової дивізії, яка відповідала саме за оборону південного і східного напрямків. Лише після введення у бій 11 танків і штурмових гармат 14-ї дивізії вдалося стабілізувати їхнє становище. Німці знищили два танки Т-34, 3 самохідні установки і 3 протитанкові гармати. Пізніше на ділянку оборони розвідувального батальйону були передані декілька танків «Пантера» 3 11-ї танкової дивізії [2, с. 192].

Радянська сторона активно використовувала артилерію та авіацію. Зайнявши вигідні позиції на панівних висотах, радянська артилерія отримала можливість обстрілювати майже все розташування оточених німецьких частин. Дивізіони 109-ї гаубичної бригади 16-ї артилерійської дивізії у ніч 38 на 9 січня отримали наказ бомбити оточені ворожі війська для того, щоб унеможливити їхнє перегрупування [7, арк. 10 - 12]. 
3 повітря удари по ворогу здійснювали літаки 1-го штурмового авіаційного полку 5-ї повітряної армії. 8 січня група із 7 літаків Іл-2 з 667-го штурмового авіаполку знищила 5 танків, 10 автомобілів і до 2 рот піхоти. У цей же день інша група радянських літаків знищила до 16 автомобілів із піхотою. Німецька авіація протягом 8 січня збила 9 радянських винищувачів [13, с. 51].

Через деякий час оточеним німецьким дивізіям почало бракувати боєприпасів, пального й продовольства. Частини їхнього забезпечення знаходилися за колом оточення. Наприклад, обози й підрозділи забезпечення 14-ї танкової дивізії ще перед боями за Кіровоград були розташовані в Хмельовому, Злинці та Великій Висці, i, крім зв'язку з бойовими частинами дивізіі, ніяких інших контактів із ними не мали.

У Великій Висці німцями було сформовано й відправлено в напрямку Лелеківки колону вантажівок із необхідними предметами забезпечення. Під вогневим прикриттям декількох бронетранспортерів і встановлених на вантажівках ручних кулеметів колоні вдалося прорвати коло оточення й прибути в розташування дивізій. У ніч на 9-те січня в напрямку Лелеківки було відправлено ще одну колону, яка також успішно дісталася місця призначення.

Для того, щоб перервати постачання боєприпасів, пального й продовольства німецьким дивізіям, радянські частини провели наступ на Велику Виску, який, однак, закінчився невдало. Німецький гарнізон села й підрозділи 276-го дивізіону зенітної артилерії зуміли відбити наступ і втримати Велику Виску як найближчу базу забезпечення оточених у Лелеківці дивізій.

Згодом у цьому вже не було потреби, бо Гітлер під тиском наполягань командування 8-ї армії та 47-го танкового корпусу дозволив 14-й танковій, 10-й танково-гренадерській і 376-й піхотній дивізіям залишити околиці Лелеківки. Вихід із оточення німці запланували на ніч 39 на 10 січня. Були проведені певні приготування. У місці запланованого прориву 3 півдня були розташовані 1-й батальйон 103-го танково-гренадерського полку і розвідувальний батальйон 14-ї дивізії. Організувавши таким чином прикриття, німці вийшли 3 оточення. Спочатку - 10-та танково-гренадерська, а за нею - 376-та піхотна дивізії. В ар'єргарді рухались підрозділи 14-ї танкової дивізії. Вийшовши з оточення, 14-та дивізія прибула на залізничну станцію Шостаківка, а згодом зайняла нові позиції між Грузьким і Карлівкою [2, с. 196]. 
3 опублікованих джерел відомо, що німці вийшли з оточення через місце, яке мав контролювати 39-й полк 13-ї гвардійської стрілецької дивізії. Але підрозділи 39-го полку 3 невідомих причин не зуміли вчасно зайняти потрібні позиції. Винними у цьому, як зазначається в історичній літературі, були тимчасово виконуючі обов'язки керівників дивізії та полку полковник Лайтадзе і майор Фаворов. Щоб виправити ситуацію, начальник штабу 13-ї дивізії полковник Т.В. Бєльський спрямував у місце прориву німців 4-й окремий винищувально-протитанковий дивізіон і навчальний батальйон [18, с. 225-226].

В історичні науці періоду СРСР щодо оцінки результатів боїв у Лелеківці і Злодійській балці панувала чітка позиція: радянським військам вдалося знищити більшу частину ворога $\mathrm{i}$ лише його невелика група зуміла вирватися 3 оточення. Витоки цієї позиції слід шукати у спогадах керівників Кіровоградської наступальної операції: командувача 2-м УФ I.С. Конєва [15], командувача 5-ї гвардійською армією О.С. Жадова [6], начальника штабу 32-го гвардійського корпусу I.О. Самчук [18] та ін.

Хоча у багатьох журналах бойових дій радянських частин без найменшої деталізації також вказується, що більшість оточених під Кіровоградом гітлерівців була знищена. Але все ж таки архівні документи дають певні статистичні дані про втрати ворога. Так у Журналі бойових дій 2-го Українського фронту вказується, що 5-та гвардійська армія 9 січня проводить бої 3 Лелеківським угрупованням, яке нараховує 150 танків [1, арк. 22]. Начальник штабу 5-ї армії генерал-майор М.I. Лямін у бойовому донесенні від 10 січня 1944 р. повідомляє, що поблизу Лелеківки виявлено 400 розбитих автомашин, 52 танки і 50 самохідних гармат ворога [4, с. 53]. В документах 7-го мехкорпуса зазначається, що у Лелеківці виявлено 60 танків і 11 самохідних гармат.

У Журналі бойових дій 8-ї гвардійської бомбардувальної авіаційної дивізії вказується, що 9 січня іiі підрозділи завдали удару по розташованій в околицях Лелеківки німецькій техніці кількістю до 500 одиниць. Льотчики дивізії повідомили про знищення і пошкодження до 50 танків і автомашин цього дня, а також розсіяння до чотирьох батальйонів піхоти.У Журналі бойових дій 8-ї авіадивізії за 10 січня вказується: «Благодаря массированным действиям нашей авиации Лелековский плацдарм 
в течении дня 9.1.44 был ликвидирован. ... разгромлено 3 пд. и 1 тд. противника. Противник на поле боя оставил до 5 тысяч трупов и до 500 единиц танков и автомашин» [12, арк. 68-68 зв.; 69 зв.].

Напевно, вказана у радянських документах кількість гітлерівських солдат та офіцерів, а також техніки перебільшена. Хоча наявність поблизу Лелеківки великої кількості німецької техніки цілком вірогідна. Справа в тім, що у Кіровограді в грудні 1943 р. - січні 1944 р. розташовувався збірний пункт аварійних машин (ЗПАМ) 8-ї піхотної і 1-ї танкової армій, що пояснює наявність у місті, на його залізничній станції, а також на роз'їзді Лелеківка значних обсягів ворожої техніки.

У середині ХХ ст. у Німеччині вийшли друком перші дослідження, присвячені історії окремих німецьких дивізії. Ці праці були написані, як правило, колишніми командирами, офіцерами чи солдатами цих дивізій. У 1957 р. вже згадуваний Р. Грамс опублікував книгу з історії 14-ї танкової дивізії [2], а генераллейтенант Август Шмідт у 1963 р. написав історію 10-ї танковогренадерської дивізії. Автори цих книг, описуючи бої в околицях Лелеківки, зазначають, що німецьким дивізіям вдалося вийти 3 оточення майже без втрат.

На жаль, автори вказаних книг не наводять жодних статистичних даних щодо дивізій, а обмежуються лише загальними формулюваннями. Тому нині неможливо достовірно визначити ні кількісний склад розташованих у Лелеківці дивізій, ні їхні втрати під час перебування в оточенні і виходу з нього. Зрозуміло одне: за час боїв 5-6 січня перелічені гітлерівські дивізії зазнали серйозних втрат і поблизу Лелеківки їхні кількісні показники були далекими від штатної комплектації.

Висновки. Отже, відзначимо, що під час проведення Кіровоградської наступальної операції військам 2-го УФ вдалося оточити під Кіровоградом три німецькі дивізії: 14-ту танкову, 10-ту танковогренадерську та 376-ту піхотну. В оперативному оточенні дивізії перебували 7 - 10 січня 1944 р. Протягом цього часу радянські війська неодноразово здійснювали спроби їх знищити. Проте у ніч 38 на 9 січня німецькі дивізії зуміли вийти 3 оточення i зайняли позиції на захід від Кіровограда. Відкритим залишається питання щодо точної кількості німецьких військ, а також їхніх втрат за період перебування в оточенні та прориву з нього. 
1. Выписка из журнала боевых действий 2-го Украинского фронта за январь месяц 1944 г. Период с 13.01.1943 по 31.01.1944 г. - Центральный архив Министерства обороны Российской Федерации (далее - ЦАМО РФ).Ф. 240. - Оп. 2779. - Д. 1130.

2. Грамс Р. 14-я танковая дивизия. 1940 - 1945 / Р. Грамс. M., 2014. $-446 \mathrm{c}$.

3. Грииюк В.M. Кіровоградська наступальна операція 1944 р. / В.М. Грицюк // Військово-науковий вісник. Вип. 17. - 2012. - С. 18-27.

4. Грылев А.Н. Днепр-Карпаты-Крым. Освобождение Правобережной Украины и Крыма в 1944 году / А.Н. Грылев. М., 1970. -352 c.

Дащенко В.В. Щоб пам'ятали. Кіровоградщина в роки Великої Вітчизняної війни (1941-1945). Історикопубліцистичний нарис В.В. Даценко. - Кіровоград, 2010. $304 \mathrm{c}$.

6. Жадов А.С. Четыре года войны / А.С. Жадов. - М., 1978. $-334 \mathrm{c}$.

7. Журнал боевых действий 109-й гаубичной бригады. Период с 01.01.1944 по 31.01.1944 г. - ЦАМО РФ. Ф. 9937. - Оп. 1. - Д. 23.

8. Журнал боевых действий 111-й стрелковой дивизии. Период с 01.01.1944 по 30.12.1944 г. - ЦАМО РФ. Ф. 1306. - Оп. 1. - Д. 37.

9. Журнал боевых действий 18-го танкового корпуса. Период с 01.01.1944 по 31.01.1944 г. - ЦАМО РФ. Ф. 3415. - Оп. 1. - Д. 53.

10. Журнал боевых действий 41-й гвардейской танковой бригады 7-го механизированного корпуса. Период с 01.01.1944 по 14.05.1944 г. - ЦАМО РФ. - Ф. 3131. Оп. 1. - Д. 2.

11. Журнал боевых действий 5-й гвардейской армии. Период с 01.01.1944 по 31.01.1944 г. - ЦАМО РФ. - Ф. 328. Оп. 4852. - Д. 168.

12. Журнал боевых действий 8-й гвардейской бомбардировочной авиационной дивизии. Период с 16.07.1943 по 19.06.1944 г. - ЦАМО РФ. - Ф. 20042. - Оп. 1. - Д. 13.

13. Колечкин В.П. Авиация в боях под Кировоградом в январе 1944 г. В.П. Колечкин // Авиация и время. - 2003. № 6. - C.49-52.

Колєчкін В.П. Дещо про періодизацію визволення Кіровоградщини у січні 1944 р. / В.П. Колєчкін // Між Бугом і Дніпром. Науково-краєзнавчий вісник Центральної України. - Випуск II. - Кіровоград, 2014. - С. 16-23.

15. Конєв І.С. Записки командуючого фронтом 1943 1945 / I. С. Конєв. - К., 1983. -619 с. 
16. Кром М.Г. Кіровоградська наступальна операція 1944 року / М.Г. Кром // Україна в полум'ї війни 19411945 pp. - K., 2005. - C. 261-271.

17. Полевой Б.М. Эти четыре года. Из записок военного корреспондента. Книга первая и вторая / Б.М. Полевой // Собрание сочинений в девяти томах. - Т. 7. - М., 1984.

18. Самчук И.А. Тринадцатая гвардейская. Боевой путь Тринадцатой гвардейской Полтавской ордена Ленина дважды Краснознаменной орденов Суворова и Кутузова стрелковой дивизии (1941-1945) И.А. Самчук. - М., 1971. - 280 с.

Надійшла до редколегії 27.10.2017 p.

Рецензент: O. В. Турчак, доктор юридичних наук, доцент, начальник НДЛ (військово-історичних досліджень) Наукового центру Національної академії сухопутних військ імені гетьмана Петра Сагайдачного, м. Львів

\section{Shevchenko Boris. \\ TO THE HISTORY OF KIROVOHRAD OFFENSIVE OPERATION OF 2nd UKRAINIAN FRONT IN JANUARY 1944}

The article examines a little-known page of the history of Kirovohrad offensive operation, based on archival documents, memoirs and historical literature. On January 5-16, 1944, the troops of the 2 nd Ukrainian Front surrounded several divisions of the 47th Panzer Corps of the 8th Field Wehrmacht Army in the western and north-western outskirts of Kirovohrad. The author examines in detail the hostilities between the German and Soviet troops on January 6-10, 1944, presents the list of Nazi divisions, that have been encircled, and attempts are made to define their losses.

Key words: Kirovohrad offensive operation, 2nd Ukrainian Front, 8th Field Army of the Wehrmacht, operational environment, division, departures, railroad and highway roads. 